\title{
STRATEGI PEMASARAN TEH CELUP GOALPARA INDUSTRI HILIR TEH PT. PERKEBUNAN NUSANTARA VIII \\ (Studi Kasus Industri Hilir Teh PTPN VIII Bandung, Provinsi Jawa Barat)
}

\author{
MAULIDA NABILA ROSYALINA*, GEMA WIBAWA MUKTI \\ Program Studi Agribisnis, Fakultas Pertanian, Universitas Padjadjaran \\ *Email: maulidanabrlina@gmail.com
}

\begin{abstract}
ABSTRAK
Perkebunan Negara di Jawa Barat yang bergerak di bidang komoditas teh adalah PT. Perkebunan Nusantara VIII (PTPN VIII). PTPN VIII memiliki unit usaha dengan tujuan mengembangkan produk hulu teh menjadi produk hilir teh yang dikenal dengan Industri Hilir Teh (I-Teh). I-Teh PTPN VIII memproduksi beberapa produk teh dengan salah satu mereknya adalah Goalpara. Teh Goalpara merupakan teh produksi dalam negeri yang dibuat dari bahan baku yang berasal dari perkebunan milik sendiri. Pada kenyataannya, Teh Celup Goalpara mengalami masalah dalam memasarkan produknya seperti kurangnya distribusi ke swalayan-swalayan kecil, promosi yang kurang optimal yang mengakibatkan masih banyak masyarakat yang belum mengetahui produk tersebut dan persaingan dengan produk teh celup sejenis yang semakin ketat. Tujuan dari penelitian ini adalah untuk merancang strategi pemasaran yang tepat melalui alat analisis SWOT dan AHP. Metode SWOT digunakan untuk mengetahui keadaan internal dan keadaan eksternal pada perusahaan tersebut kemudian menggunakan metode AHP yang digunakan untuk memilih prioritas alternatif strategi pemasaran yang tepat. Matriks IFE memiliki nilai tertimbang 2,58 yang artinya posisi internal yang kuat, matriks EFE memiliki nilai tertimbang 2,46 yang artinya perusahaan merespon dengan baik peluang dan ancaman yang ada. Posisi perusahaan berada pada kuadran V yang artinya "Hold and Maintain". Dari hasil pengolahan AHP diketahui strategi yang yang dipilih adalah meningkatkan pelatihan terhadap karyawan $(0,241)$ dan meningkatkan penjualan dengan penerapan digital marketing $(0,202)$.
\end{abstract}

Kata kunci: AHP, IFE, EFE, Strategi Pemasaran, SWOT

\begin{abstract}
Nation plantation in West Java which moving in tea commodity field is PT. Perkebunan Nusantara VIII (PTPN VIII). PTPN VIII has business unit with purposes in developing product upstream tea to become downstream tea which called with downstream tea industries (I-Teh). PTPN's I-Teh produced some of tea product with the one brand product is Goalpara's. Goalpara's tea is nation's tea production which be made from originated raw material from self own-plantation. Truth is goalpara's tea bag has problem in marketed in its product for example is lack of distribution to small markets, less optimal in promotion which caused by many society not knowing of that product and competition with similar tea bag's product is tougher. The purpore from this reasearh is to formulation of marketing strategy properly through analytic tools SWOT and AHP. SWOT method used to knowing internal and external situation in the company and then using AHP method which used to choosing the right alternative marketing strategy's priority properly. IFE matrix has score 2.58, this indicates the strong internal position, EFE matrix has score 2.46 indicates that the company responses well the opportunity and Threats that exist within the company. The position of the company is in cell $V$, it can be concluded that the appropriate strategy is Hold and maintain. The result with AHP showed that the marketing strategy a top priority can be applied in I-Teh PTPN VIII
\end{abstract}


is improve training for employees $(0,241)$ and increase sales with the application of digital marketing $(0,202)$.

Keyword: AHP, IFE, EFE, Marketing Strategy Marketing, SWOT

\section{PENDAHULUAN}

Perkebunan negara di Jawa Barat yang bergerak di bidang komoditas teh adalah PT. Perkebunan Nusantara VIII (PTPN VIII). PTPN VIII memiliki unit usaha dengan tujuan mengembangkan produk hulu teh menjadi produk hilir teh yang dikenal dengan Industri Hilir Teh (I-Teh). I-Teh PTPN VIII memproduksi beberapa produk teh dengan salah satu mereknya adalah Goalpara. Teh Goalpara merupakan teh produksi dalam negeri yang dibuat dari bahan baku yang berasal dari perkebunan milik sendiri.

Produk teh dipasarkan dalam berbagai bentuk diantara lainnya teh seduh, teh kemasan botol dan teh celup. Di Indonesia sendiri, semakin banyak brand teh celup di pasaran. Masyarakat mengenal beberapa merek teh celup ternama yang ada di pasaran seperti Cap Botol, Tong Tji, Cap, Bendera, Poci, Gopek dan 2 Tang (Tabel 1).

\section{Tabel 1. Top Brand Award Kategori} Teh tahun 2018

\begin{tabular}{lcc}
\hline \multicolumn{1}{c}{ Merek } & TBI & TOP \\
\hline Teh Poci & $22,1 \%$ & TOP \\
Cap Bendera & $15,8 \%$ & TOP \\
Cap Botol & $10,9 \%$ & \\
2 TANG & $5,9 \%$ & \\
Bandulan & $5,4 \%$ & \\
\hline
\end{tabular}

Sumber: Top Brand Indonesia, 2018

Berdasarkan Tabel 1, bahwa di Indonesia, Top Brand Award untuk kategori produk teh yang banyak diminati oleh masyarakat pada tahun 2018 adalah Teh Poci yang menduduki peringkat pertama. Sedangkan, untuk produk teh celup dengan merek Goalpara belum memasuki Top Brand Award. Top Brand Award didasarkan atas hasil riset terhadap konsumen di Indonesia. Pemilihan merek teh terbaik berdasarkan pilihan konsumen. Artinya, merek teh celup Goalpara sendiri belum memiliki brand image di kalangan masyarakat, hanya merekmerek tertentu yang diketahui oleh konsumen. Pemilihan Top Brand Award oleh konsumen ini dilakukan melalui survei dari Frontier Consulting Group di sebelas kota besar di Indonesia yakni Jakarta, Bandung, Semarang, Surabaya, Medan, Makassar, Pekanbaru, Balikpapan, Denpasar, Palembang dan Samarinda.

Kegiatan pemasaran yang dilakukan ITeh PTPN VIII dalam memasarkan produk Teh Celup Goalpara adalah menjualnya ke pasar tradisional dan beberapa supermarket. Akan tetapi, produk teh celup Goalpara sendiri masih sulit ditemukan masyarakat dikarenakan hanya dapat ditemukan di beberapa supermarket seperti Yogya, Superindo, dan Borma. Berbeda halnya dengan produk teh celup lainnya yang mudah ditemukan dikarenakan sudah memasuki hampir seluruh supermarket dan minimarket 
yang ada di Indonesia. Kegiatan promosi yang dilakukan oleh I-Teh PTPN VIII dalam memasarkan Teh Celup Goalpara adalah dengan kegiatan promosi below the line seperti adanya bazar, grebek pasar, events dan sales promotion. Tujuan dari kegiatan promosi ini adalah untuk memperkenalkan produk Teh Celup Goalpara kepada masyarakat. Akan tetapi kegiatan promosi yang dilakukan I-Teh PTPN VIII masih kurang optimal.

Jika melihat dari permasalahan yang ada yaitu pemasaran produk Teh Celup Goalpara dengan lingkup pasar yang masih terbatas, promosi kurang optimal dan

\section{METODE PENELITIAN}

Penelitian ini merupakan penelitian kualitatif dengan teknik studi kasus. Menurut Creswell (2012) dalam Sugiyono (2017), studi kasus yaitu salah satu jenis penelitian kualitatif, dimana peneliti melakukan eksplorasi secara mendalam terhadap program, kejadian, proses, aktivitas, terhadap satu atau lebih orang. Suatu kasus terikat oleh waktu dan aktivitas dan peneliti melakukan pengumpulan data secara mendetail dengan menggunakan berbagai prosedur pengumpulan data dan dalam waktu yang berkesinambungan.

Data yang dikumpulkan dalam penelitian ini meliputi data primer dan data sekunder. Menurut Sugiyono (2017), data primer adalah sumber data yang langsung memberikan data kepada pengumpul data. persaingan dengan produk teh celup lainnya yang cukup ketat. Berdasarkan kondisi tersebut, menuntut I-Teh PTPN VIII, memerlukan strategi pemasaran yang tepat agar dapat bersaing dengan perusahaan lainnya. Strategi pemasaran merupakan suatu upaya untuk mencapai suatu tujuan perusahaan dalam hal bersaing dengan pesaing perusahaan lainnya. Dengan mempertimbangkan hal tersebut, penelitian ini bertujuan untuk merumuskan strategi pemasaran produk teh celup goalpara menggunakan analisis SWOT dan menyusun alternatis strategi menggunakan Analytical Hierarchy Process (AHP).

Data primer diperoleh dari pengamatan langsung serta wawancara langsung dengan pihak-pihak yang terkait dengan objek penelitian. Data primer dalam penelitian ini diperoleh dari informan yang dipilih secara sengaja (purposive sampling) dengan mempertimbangkan informan yang dipilih memiliki kontribusi yang besar dalam perumusan strategi dan pelaksanaan strategi pemasaran di perusahaan serta berperan dalam pengambilan keputusan.

Sedangkan data sekunder merupakan sumber data yang tidak secara langsung memberikan data kepada sumber data seperti dari dokumentasi. Data sekunder digunakan sebagai data pendukung dari data primer yang diperoleh dari hasil wawancara. Data sekunder dalam penelitian ini didapatkan dari penelusuran internet seperti data dari BPS, literatur kepustakaan, website Direktoral 
Jenderal Perkebunan, skripsi, catatan, jurnal, maupun dokumen dari kantor I-Teh PTPN VIII.

Tujuan dari penelitian ini adalah merumuskan strategi pemasaran teh celup goalpara. Adapun teknik dalam perumusan strategi dalam tiga tahap kerangka pengambilan keputusan, yaitu tahap pengumpulan input, tahap pencocokan dan tahap pengambilan keputusan. Tahap pengumpulan input yaitu mengidentifikasi informasi yang diperlukan dalam menentukan strategi yang terdiri atas analisis faktor internal dan eksternal, kemudian disusun ke dalam matriks Internal Factor Evaluation (IFE) dan External Factor Evaluation (EFE).

Tahap pencocokan dilakukan dengan menggunakan dua alat bantu analisis yaitu matriks IE dan matriks SWOT. Matriks IE untuk mengetahui posisi I-Teh PTPN VIII saat ini yang diperoleh dari matriks IFE dan EFE. Sedangkan matriks SWOT bertujuan untuk merumuskan alternatif strategi yang bisa diterapkan oleh I-Teh PTPN VIII.

Tahap pengambilan keputusan bertujuan untuk menetapkan alternatif strategi yang bisa diterapkan oleh I-Teh PTPN VIII, menetapkan alternatif strategi yang menjadi prioritas dengan menggunakan Analytical Hierarchy Process (AHP).

\section{HASIL DAN PEMBAHASAN}

Matriks Internal Factor Evaluation (IFE)

Pada Tabel 2, matriks IFE untuk kekuatan I-Teh PTPN VIII, yang menjadi kekuatan utama adalah ketersediaan bahan baku teh dengan skor 0,552. Hal ini dibuktikan bahwa I-Teh PTPN VIII memiliki perkebunan teh sendiri sehingga dapat menunjang I-Teh PTPN VIII dalam memproduksi teh celup Goalpara. Kekuatan kedua adalah karyawan berkualitas dengan skor 0,484. Kekuatan ketiga adalah keamanan produk dengan skor 0,336. Kekuatan keempat dan kelima adalah harga produk dan teknologi dalam produksi dengan skor 0,312. Sedangkan yang menjadi kelemahan utama I-Teh PTPN VIII adalah promosi yang kurang optimal dengan bobot tertinggi 0,138 dan dengan rating 1 (kelemahan sangat kuat). Hal ini dikarenakan promosi yang dilakukan oleh I-Teh PTPN VIII memang belum optimal. Promosi yang dilakukan hanya promosi below the line saja. Skor total nilai skor semua dari matriks IFE adalah sebesar 2,58 (>2,5). Skor ini menunjukkan bahwa posisi internal perusahaan adalah termasuk ke dalam kategori baik. 
Tabel 2. Matriks IFE I-Teh PTPN VIII

\begin{tabular}{|c|c|c|c|c|}
\hline No & Faktor-faktor Strategi Internal & Bobot & Rating & Nilai Skor \\
\hline \multicolumn{5}{|c|}{ Kekuatan } \\
\hline 1. & Karyawan berkualitas & 0,121 & 4 & 0,484 \\
\hline 2. & Ketersediaan bahan baku teh & 0,138 & 4 & 0,552 \\
\hline 3. & Keamanan produk & 0,112 & 3 & 0,336 \\
\hline 4. & Harga produk & 0,104 & 3 & 0,312 \\
\hline 5. & Teknologi dalam produksi & 0,104 & 3 & 0,312 \\
\hline \multicolumn{5}{|c|}{ Kelemahan } \\
\hline 6. & Promosi yang kurang optimal & 0,138 & 1 & 0,138 \\
\hline 7. & Keterbatasan tempat pemasaran & 0,121 & 1 & 0,121 \\
\hline 8. & Produk kurang variatif & 0,086 & 2 & 0,172 \\
\hline 9. & Pemesanan persediaan bahan kemasan & 0,076 & 2 & 0,152 \\
\hline & Total & 1.0 & & 2,58 \\
\hline
\end{tabular}

Matriks External Factor Evaluation (EFE)

Berdasarkan hasil pengolahan matriks EFE pada Tabel 3, total skor yang diperoleh adalah sebesar 2,46. Total skor rata-rata tertimbang I-Teh PTPN VIII mengindikasikan bahwa I-Teh PTPN VIII sudah merespon baik faktor-faktor eksternal namun belum maksimal dalam memanfaatkan peluang yang ada dan belum maksimal dalam menghindari ancaman-ancaman dari luar perusahaan. Berdasarkan matriks EFE, perkembangan teknologi informasi merupakan faktor peluang terbesar dengan skor 0,736 yang bisa dimanfaatkan oleh I-Teh PTPN VIII.
Kemudian, faktor peluang kedua yaitu kerjasama dengan minimarket dan rumah makan dengan skor 0,644 dan faktor peluang terakhir adalah gaya hidup dengan skor 0,345 .

Sedangkan faktor ancaman utama bagi I-Teh PTPN VIII adalah banyak pesaing teh sejenis dan brand image dengan bobot 0,184 dan rating 1 (ancaman kuat). Produk teh celup goalpara memiliki banyak pesaing teh celup lainnya dan sulit membentuk brand image dengan nama Goalpara dikarenakan masyarakat luas hanya mengenal produk teh celup seperti Sariwangi, Tong Tji dan merek lainnya. 
Tabel 3. Matriks EFE I-Teh PTPTN VIII

\begin{tabular}{llccc}
\hline No & \multicolumn{1}{c}{ Faktor Eksternal } & Bobot & Rating & Nilai Skor \\
\hline \multicolumn{4}{l}{ Peluang } \\
1. & Perkembang teknologi informasi & 0,184 & 4 & 0,736 \\
2. & Gaya hidup sehat & 0,115 & 3 & 0,345 \\
3. & Kerjasama dengan minimarket dan rumah makan & 0,161 & 4 & 0,644 \\
\hline \multicolumn{4}{l}{ Ancaman } \\
\hline 4. & Banyak pesaing teh sejenis & 0,184 & 1 & 0,184 \\
5. & Brand image & 0,184 & 1 & 0,184 \\
6. & Perkembangan teknologi & 0,172 & 2 & 0,344 \\
\hline & Total & $\mathbf{1 . 0}$ & \\
\hline
\end{tabular}

\section{Matriks IE}

Berdasarkan Gambar 1, analisis faktor internal dengan menggunakan matriks IFE didapat skor 2,58 dan analisis faktor eksternal dengan menggunakan matriks EFE didapat skor 2,46, maka diperoleh pemetaan posisi perusahaan pada Kuadran V yaitu strategi "menjaga dan mempertahankan". Strategi yang dapat diterapkan oleh I-Teh PTPN VIII adalah strategi pengembangan pasar dan strategi penetrasi pasar. Dengan ini artinya perusahaan harus melakukan pencarian pangsa pasar baru untuk perluasan pasar dengan didukung kekuatan dan peluang yang dimiliki oleh perusahaan.Strategi penetrasi pasar berupaya mencari pangsa pasar yang lebih besar untuk produk atau jasa yang sudah ada melalui pemasaran yang gencar. Pengembangan produk lebih berupaya meningkatkan penjualan dengan memperbaiki produk atau jasa yang sudah ada seperti menciptakan inovasi produk, memperluas wilayah pemasaran, melakukan promosi serta menjaga kualitas produk.

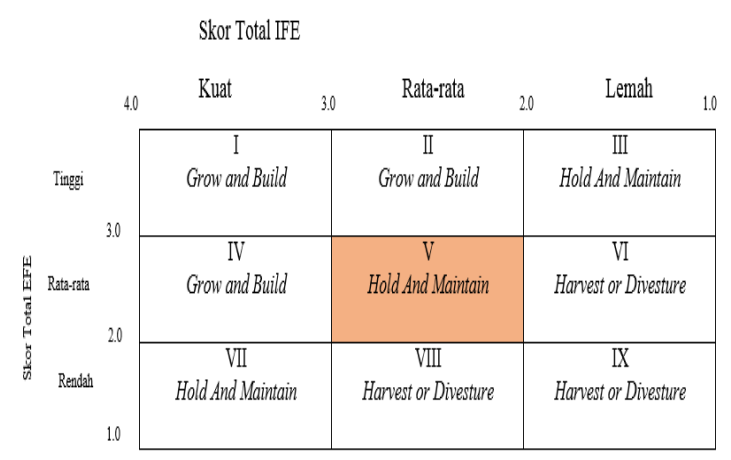

Gambar 1. Matriks IE

Alternatif strategi yang dihasilkan pada Matriks IE merupakan strategi umum yang tidak akan memiliki implementasi strategi yang jauh lebih teknis ditingkat perusahaan. Oleh karena itu, matriks IE akan dilengkapi pada matriks SWOT yang memberikan rincian lebih jelas mengenai alternatif strategi yang tepat untuk dilakukan oleh perusahaan. 


\section{Matriks SWOT}

Analisis matriks SWOT merupakan alat analisis untuk mencocokan beberapa tipe strategi pada kondisi lingkungan internal berupa kekuatan dan kelemahan serta lingkungan eksternal berupa peluang dan ancaman yang dihadapi perusahaan. Dengan menggunakan matriks SWOT, akan disusun beberapa formulasi strategi pemasaran yang dapat dijalankan oleh perusahaan. Matriks SWOT terdiri atas strategi S-O (Strength-Opportunities), strategi S-T (Strengths-Threats), strategi W-O (Weakness-Opportunities), dan strategi W-T (Weakness- Threats). Hasil analisis matriks SWOT dapat dilihat pada Tabel 4.

Tabel 4. Matriks SWOT

\begin{tabular}{|c|c|c|}
\hline IFE & $\begin{array}{l}\text { KEKUATAN (S) } \\
\text { 1) Karyawan yang berkualitas } \\
\text { 2) Ketersediaan bahan baku teh } \\
\text { 3) Keamanan produk } \\
\text { 4) Harga produk } \\
\text { 5) Teknologi dalam produksi }\end{array}$ & $\begin{array}{l}\text { KELEMAHAN }(\boldsymbol{W}) \\
\text { 1) Promosi yang kurang optimal } \\
\text { 2) Keterbatasan tempat } \\
\text { pemasaran } \\
\text { 3) Produk Kurang variatif } \\
\text { 4) Pemesanan persediaan bahan } \\
\text { kemasan }\end{array}$ \\
\hline $\begin{array}{l}\text { PELUANG (O) } \\
\text { 1) Kerjasama dengan } \\
\text { minimarket dan } \\
\text { rumah makan } \\
\text { 2) Gaya hidup sehat } \\
\text { 3) Perkembangan } \\
\text { Teknologi Informasi }\end{array}$ & $\begin{array}{l}\text { STRATEGI } \boldsymbol{S} \text {-O } \\
\text { 1. Meningkatkan pelatihan } \\
\text { terhadap karyawan } \\
\text { 2. Mempertahankan harga produk } \\
\text { di pasaran }\end{array}$ & $\begin{array}{l}\text { STRATEGI } \boldsymbol{W} \text {-O } \\
\text { 1. Meningkatkan penjualan } \\
\text { dengan penerapan digital } \\
\text { marketing } \\
\text { 2. } \\
\text { Mengoptimalkan saluran } \\
\text { distribusi yang ada untuk } \\
\text { meningkatkan penjualan dalam } \\
\text { persaingan pasar }\end{array}$ \\
\hline $\begin{array}{l}\text { ANCAMAN (T) } \\
\text { 1) Banyak pesaing teh } \\
\text { sejenis } \\
\text { 2) Brand image } \\
\text { 3) Perkembangan } \\
\text { teknologi }\end{array}$ & $\begin{array}{l}\text { STRATEGI } \boldsymbol{S} \text { - } \boldsymbol{T} \\
\text { 1. Menjaga kualitas produkdan } \\
\text { mutu teh } \\
\text { 2. Memperkenalkan brand image } \\
\text { produk teh celup Goalparadi } \\
\text { masyarakat }\end{array}$ & $\begin{array}{l}\text { STRATEGI } \boldsymbol{W} \text {-T } \\
\text { 1. Meningkatkan kegiatan } \\
\text { promosi secara optimal } \\
\text { 2. Memproduksi varian baru }\end{array}$ \\
\hline
\end{tabular}

Berdasarkan analisis matriks SWOT yang telah dilakukan sebelumnya (Tabel 4), telah diperoleh delapan alternatif strategi pemasaran teh celup goalpara. Beberapa alternatif strategi yang telah dirumuskan tersebut belum tentu dapat dilaksanakan semuanya bersamaaan, sehingga perlu dilakukan prioritas dalam pelaksanaannya secara bersama-sama. Penentuan prioritas alternatif strategi yang dihasilkan melalui matriks SWOT akan dilakukan dengan menggunakan Analytical Hierarchy Process (AHP). 


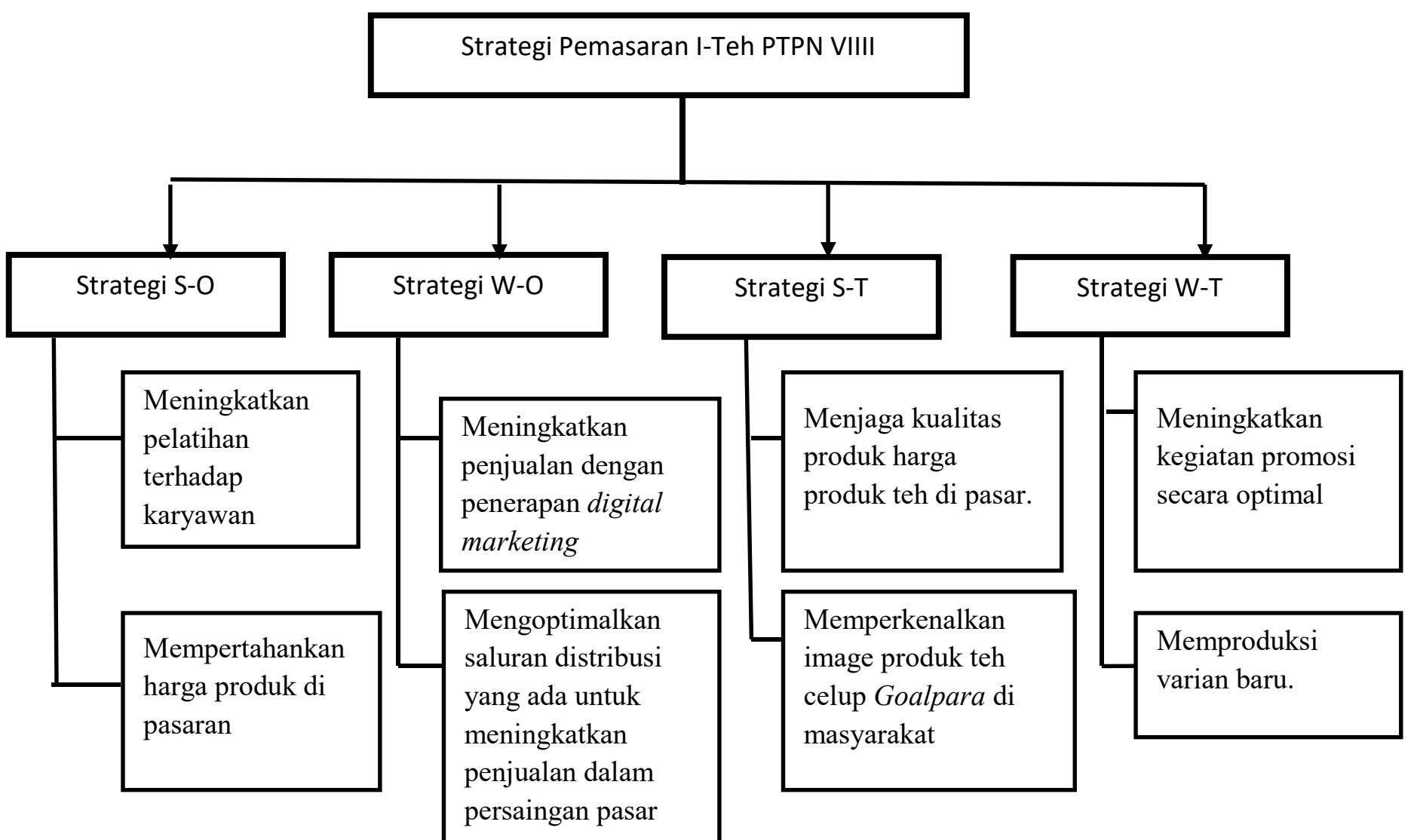

\section{Gambar 2. Struktur Hierarki}

Berdasarkan hasil pengolahan data AHP, diperoleh urutan prioritas alternatif strategi I-Teh PTPN VIII (Tabel 5).

Tabel 5. Alternatif Strategi

\begin{tabular}{lc}
\hline Alternatif strategi & Nilai bobot \\
\hline Meningkatkan pelatihan terhadap karyawan & 0,241 \\
Meningkatkan penjualan dengan penerapan digital marketing & 0,202 \\
Mengoptimalkan saluran distribusi yang ada untuk meningkatkan penjualan & 0,118 \\
dalam persaingan pasar & 0,108 \\
Mempertahankan harga produk di pasaran & 0,095 \\
Menjaga kualitas produk dan mutu the & 0,095 \\
Memperkenalkan image produk teh celup Goalpara di masyarakat & 0,085 \\
Meningkatkan kegiatan promosi secara optimal & 0,044 \\
Memproduksi varian baru & \\
\hline
\end{tabular}

\section{KESIMPULAN DAN SARAN}

1. Berdasarkan matriks internal dan eksternal I-Teh PTPN VIII berada pada kuadran $\mathrm{V}$, dengan nilai total skor pada tabel IFE sebesar 2,58 sedangkan pada tabel EFE sebesar 2,46. Kuadran $\mathrm{V}$ berarti "Menjaga dan Mempertahankan". 
2. Terdapat delapan alternatif strategi yang dihasilkan dari analisis SWOT, yaitu (1) Meningkatkan pelatihan terhadap karyawan dan mempertahankan harga produk di pasaran (S-O); (2) Meningkatkan penjualan dengan penerapan digital marketing dan mengoptimalkan saluran distribusi yang ada untuk meningkatkan penjualan dalam persaingan pasar (W-O); (3) Menjaga kualitas produk dan mutu produk serta memperkenalkan image produk teh celup Goalpara di masyarakat (S-T); (4) Meningkatkan kegiatan promosi secara optimal dan memproduksi varian baru (W-T).

3. Dari hasil olah data menggunakan metode Analytical Hierarchi Process $(A H P)$ diketahui prioritas strategi utama adalah meningkatkan pelatihan terhadap karyawan $(0,241)$ dan meningkatkan penjualan dengan penerapan digital marketing $(0,202)$.

\section{Saran}

1. Perusahaan I-Teh PTPN VIII bisa meningkatkan kualitas karyawannya dengan berbagai pelatihan sesuai dengan masing-masing bidang.

2. Perusahaan I-Teh PTPN VIII mengoptimalkan promosi melalui digital marketing seperti membuat website mengenai teh celup goalpara dan teh walini yang berisikan tentang sejarah perusahan, produk teh, manfaat dari produk dan lain-lain; mengoptimalkan promosi di instagram, facebook dan mengoptimalkan penjualan online. Selain itu pun, mengoptimalkan promosi secara intensif seperti event, stand, pameran dan lainnya.

3. Perusahaan I-Teh PTPN VIII membuat varian rasa baru untuk teh celup goalpara selain teh hitam, seperti membuat varian teh melati, teh dengan varian blackcurrat, leci atau lainnya.

\section{DAFTAR PUSTAKA}

Fuad, dkk. 2006. Pengantar Bisnis. Jakarta: PT. Gramedia Pustaka Utama.

Kotler, Philip. 1995. Dasar-dasar pemasaran Philip Kotler, Gary Armstrong; alih bahasa, Wihelmus W. Bakowatun; editor, Heru Sutojo. Edisi VI. Intermedia: Jakarta.

Kotler dan Keller. 2009. Manajemen Pemasaran. Jilid I. Edisi ke 13 Jakarta: Erlangga.

Rangkuti, F. 2016. Analisis SWOT: Teknik Membedah Kasus Bisnis Cara Perhitungan Bobot, Rating dan OCAI. Gramedia Pustaka Utama: Jakarta.

Saaty T. L. 1993. Proses Hierarki Analitik untuk Pengambilan Keputusan dalam Situasai yang Kompleks (Terjemahan). PT Pustaka Binaman Pressindo. Jakarta. 
Sunyoto, Danang. 2015. Strategi Pemasaran. Jakarta: CAPS (Center for Academic Publishing Service).

Sugiyono. 2017. Metode Penelitian Kualitatif. Bandung: Alfabeta.

Tjiptono, Fandy. 2015. Strategi Pemasaran Edisi 4. Yogyakarta: C.V. Andi Offset.
Top Brand Award. 2018. "Top Brand Index Kategori Teh 2018" melalui $<$ http://www.topbrandaward.com/top-brandsurvey/surveyresult/top_brand_index_2018_fase $1>$

Umar, Husein. 2008. Strateguc Management un Action. Jakarta: PT. Gramedia Pustaka Utama. 